\title{
Effect of hemorrhagic shock on intestinal anastomoses' healing
}

\author{
Efeito do choque hemorrágico na cicatrização de anastomoses intestinais
}

Talita Virgínia Fernandes de Oliveira, João Victor de Sousa Cabral, Juliane Patrícia Grigório da Silva, Scarlett O'hara Gabriela Medeiros Gonçalves Pereira, Vítor Brasil Medeiros, Rafael Pereira do Nascimento, Ítalo Medeiros Azevedo, Aldo Cunha Medeiros

\author{
Research performed at Nucleus for Experimental Surgery, Federal University of Rio Grande do Norte (UFRN), \\ Brazil. Scientific Initiation Program \\ Financial support: CNPq. \\ Conflict of interest: none \\ Correspondence address: Aldo Cunha Medeiros, Department of Surgery, Federal University of Rio Grande do \\ Norte, at Av. Nilo Peçanha 620, Natal, RN, Brazil, Email: cirurgex.ufrn@gmail.com \\ Submitted: July 10, 2015.Accepted, after review: August 26, 2015.
}

\begin{abstract}
Background/Purpose: Hypovolemia and shock is increasingly frequent in the perioperative of intestinal anastomoses, especially due to abdominal trauma. The aim of this study is to evaluate the effects of hemorrhagic shock in the healing of intestinal anastomoses in rats. Methods: It was analyzed the shock interference on the strength of ileum anastomoses. Histologically, structural changes of the anastomotic segments were assessed by two pathologists. Data are given as mean \pm SEM. The animals were randomly selected and assigned in two groups with six rats each: Group 1 - rats with hypovolemic shock (shocked+enterectomy) treated with fresh whole blood. Group 2 - rats not shocked, untreated + enterectomy. Results: The intestinal anastomosis bursting pressure of shock+enterectomy group rats was lower than in the unshocked+enterectomy group, and the difference was significant $(p=0.001)$. In the hemorrhagic shock+enterectomy group rats the density of collagen and fibrous tissue was lower and inflammation/foreign body reaction was higher than in the unshocked+enterectomy group, featuring a more immature and deficient healing. Conclusion: In conclusion, the results show that the hypovolemic shock affects the ileum wound healing, causing a decrease in the bursting pressure $(\mathrm{mmHg})$ of ileal anastomosis, leading to the fragility of the surgical wound.
\end{abstract}

Key words: Hemorrhagic shock. Enterectomy. Anastomosis. lleum. Healing.

\section{RESUMO}

Introdução/Objetivo: É cada vez mais frequente ocorrer hipovolemia e choque no perioperatório de cirurgias em que são realizadas anastomoses intestinais, especialmente em decorrência de trauma abdominal. $\mathrm{O}$ objetivo desse estudo é avaliar os efeitos do 
choque hemorrágico na cicatrização de anastomoses intestinais em ratos. Métodos: Foi feita a análise da interferência do choque na resistência de anastomoses do íleo e nas alterações histopatológicas nas zonas de anastomoses. Os animais foram selecionados aleatoriamente e alocados em 2 grupos, com seis ratos cada: Grupo 1 - ratos com choque hemorrágico, tratados com sangue total fresco + enterectomia. Grupo 2 - ratos não chocados, não tratados + enterectomia. Resultados: O grupo enterectomia+choque apresentou uma diminuição na pressão de ruptura da anastomose ileal em relação ao grupo não chocado+ enterectomia, cuja diferença revelou-se significante $(p=0,001)$. No grupo de animais submetido a choque hemorrágico ocorreu menor intensidade de formação de colágeno e tecido fibroso, bem como maior inflamação e reação do tipo corpo estranho do que no grupo não chocado+enterectomia, caracterizando uma cicatrização mais imatura e deficitária. Conclusão: Os resultados obtidos evidenciaram que o choque hemorrágico perioperatório prejudicou a cicatrização, provocando uma diminuição da pressão de ruptura da anastomose ileal, favorecendo a fragilidade da ferida cirúrgica.

Descritores: Choque hemorrágico. Enterectomia. Anastomose. Íleo. Cicatrização.

\section{INTRODUCTION}

The increasing interest in the factors involved in the healing of intestinal anastomoses is due to serious secondary clinical effects to the occurrence of dehiscence, increasing length of hospital stay and mortality ${ }^{1}$. In the gastrointestinal tract, the submucosa is the layer that provides the most part of strength of intestinal anastomoses. This consists primarily of an aggregate of collagen fibers - collagen type I (68\%) and type III (20\%) and type V (12\%) - and elastic fibers, associated with a nerve plexus and an abundant blood and lymph supply. Due to this anatomophysiological conformation, the healing process of the gastrointestinal tract is quite eficient ${ }^{2,3}$.

However, there are both local and systemic factors that interfere in the healing process of intestinal anastomoses, related to the surgical technique, the use of pharmacological agents and general conditions of the patient, among which are included immunosuppression, infection, uremia, poor nutrition, anemia, elderly and anastomosis' vascularization ${ }^{4-6}$. The reduced blood flow as a result of shock is a leading cause of failure in the healing of intestinal anastomosis, once the healing process is directly related to perfusion in the suture line ${ }^{9}$. Shock is defined as a circulatory dysfunction that causes tissue hypoxia ${ }^{1}$. Other definition addresses the shock syndrome as a sequence of events initiated by an aggressor factor, followed by endocrine-metabolic responses and failure of maintenance of homeostasis mechanisms, with decreased tissue perfusion ${ }^{7}$. In turn, tissue hypoperfusion leads to reduced oxygen availability to the cell, hypothermia, and 
metabolic acidosis ${ }^{8}$. Prolonged hypoxia, result of low blood flow conditions, has been shown to cause lesions in both the submucosa and in mucosal barrier ${ }^{6}$.

The decrease of the $\mathrm{O}_{2}$ supply leads to increased anaerobic metabolism and decreased levels of intracellular ATP and calcium, which promote significant changes in cellular function, stimulating direct or indirectly the release of inflammatory cytokines. These, on the other hand, decreases the immune function of macrophages and lymphocytes, causing immunosuppression and increased risk of infection ${ }^{9}$. There may be also stimulus to the release of toxins and bacterial translocation, which, associated with the duration of the inflammatory process, may produce irreversible changes in the tissues, causing reduced ability of intestinal absorption and inhibition of wound healing ${ }^{1,10}$.

Hypovolemia, a common occurrence in surgical emergencies, has been shown harmful to the collagen metabolism in skin lesions and abdomen. The present study is an experimental protocol using animal model of wound healing. Furthermore, the bowel is one of the organs that suffers the consequences of early ischemia on hemorrhagic shock $^{11,12}$. This is an important issue because of the frequency with which surgeries occur involving anastomosis in patients with hypovolemia - resulting from previous situations such as abdominal trauma.

The general objective of this study was to examine the interference of hemorrhagic shock in the healing of intestinal anastomoses in rats. Specifically, it was analyzed the effect of shock on the strength and histopathological changes in the anastomosis zones.

\section{METHODS}

Males Wistar rats (Rattus norvegicus albinos) were used for the research, ranging from 3 to 4 months old (weighing $265 \pm 21 \mathrm{~g}$ ). This study was submitted to and approved by the Institutional Ethics Committee on Animal Use (Protocol n 026/2013). Cautions in the use of animals followed current regulations in the Brazilian legislation for the scientific use of animals (Law No. 11,794/2008). The study was conducted in the Nucleus of Experimental Surgery, Department of Surgery, Federal University of Rio Grande do Norte, Natal, Brazil.

The animals were randomly selected and assigned to two groups with six rats each: Group 1 - rats with hypovolemic shock (shocked), treated with fresh whole blood + enterectomy. Group 2 - rats not shocked, untreated + enterectomy. The rats were kept in individual polypropylene cages in an air conditioned environment at $22^{\circ} \mathrm{C}$, with a control of particles and cycles light-dark of $12 \mathrm{~h}$. Initially the animals went through a period of seven 
days of acclimatation at the Laboratory, with ad libitum access to water and rodents chow (Presence®).

\section{Hypovolemic shock}

The animals were fasted for 12 hours before undergoing anesthesia. They were anesthetized with a mixture of Ketamine $(70 \mathrm{mg} / \mathrm{kg})$ and Xylazine $(10 \mathrm{mg} / \mathrm{kg})$, administered intramuscularly, drugs which were periodically re-administered if necessary until the end of the experiments. After stabilization of anesthesia, hypovolemic shock was installed. Silicone cannula $24 \mathrm{f}$-gauge was introduced into the right femoral artery for mean blood pressure monitoring and the left femoral vein for blood drainage and subsequent volume replacement. After a stabilization period for the animal groups, blood (5 to $7 \mathrm{~mL}$ ) was drained through the femoral vein aiming to stabilize the mean arterial pressure around $35 \mathrm{mmHg}$, monitored by a digital manometer connected to femoral artery. The hypotensive shock was maintained for $30 \mathrm{~min}$. After this period, animals of the shock group + enterectomy received resuscitation over $5 \mathrm{~min}$ with fresh rats blood. The replacement volume was equal to the blood volume lost to the establishment of the hypovolemic shock. The animals were kept in a warm microenvironment at $37^{\circ} \mathrm{C}$ in hot plate (Insight, São Paulo, Brazil), anesthetized up to the end of the experiment. The whole blood was heparinized and reinfused after 30 min of shock. The infusion was made by reinfusion of the same blood volume taken from the animals, at a constant infusion rate, using an infusion device (B.Braun, Rio, Brazil). During all infusions, blood was heated to $36.5^{\circ} \mathrm{C}$. Upon completing the treatment of shock, the animals underwent a enterectomy, surgical procedure which was also performed at non-shocked and untreated group rats.

\section{Surgical procedures}

For the surgical procedure the rats were kept under the same anesthesia as prior described and operated under aseptic technique. Following the $5 \mathrm{~cm}$ midline laparotomy, the enterectomy included a $2 \mathrm{~cm}$ segment of ileum at the distance of $10 \mathrm{~cm}$ from the ileocecal valve. Intestinal continuity was restored with end-to-end anastomosis in single suture of separate pointssuture, using 6-0 polypropylene, with the aid of surgical microscope DFV (São Paulo, Brazil), magnification 10x. The abdominal wound was then sutured with nylon 4-0.

Postoperative pain was managed with analgesia (meperidine 10mg/kg every 12 hours for the first 3 days). The animals received only water for the first 24 hours after surgery, followed by solid diet until euthanasia. The animals were weighed before surgery and immediately prior to euthanasia that occurred on the 6th day of observation, when 
rats were anesthetized again, and the ileum anastomosis were evaluated. After the observation period euthanasia was done with thiopental $100 \mathrm{mg} / \mathrm{kg}$ i.p.

\section{Anastomotic resistance evaluation}

The ileal anastomosis zone was subjected to strength test on the 6th postoperative day, proceeding up as follows: after anesthesia, another laparotomy was made, in which the intestine was cut proximal and distal to the anastomosis site. A $n^{\circ} 6$ polyethylene catheter was introduced in the ileum proximal lumen, then it was fixed with cotton thread no 00 and connected to an $\mathrm{O}_{2}$ cylinder. A second catheter was inserted into the distal end of the ileal segment and it was also tied up with cotton thread, so this connection was completely sealed. This catheter was then connected to a digital manometer. The peritoneal cavity was filled with saline solution, keeping the ileal anastomosis immersed in liquid. Then it was inflated $\mathrm{O}_{2}$ in a continuous flow rate of 0.5 liter per minute. The maximum bursting pressure of the anastomosis was considered at the time when the air bubbling appeared in the aqueous solution.

\section{Ileum anastomosis healing}

A sample of each anastomosis was fixed in $10 \%$ formalin and embedded in paraffin. $5 \mu \mathrm{m}$ sections were stained in hematoxylin and eosin and Masson trychrome, then analyzed with optic microscopy by experienced pathologists without prior knowledge of their respective groups. The histopathological analysis was made according to the criteria used by Storchet $\mathrm{al}^{19}$. Collagen deposition, fibrosis and average quantity of fibroblasts received each a positive score (Square 1). The presence of inflammatory cells (inflammation) and foreign body reaction were considered signs of poor or immature healing and received negative scores.

Square 1 - Quantification of scores resulting from the response to the wound healing

\begin{tabular}{|lrl|}
\hline \multicolumn{1}{|c|}{ BENCHMARK } & SCALE & \multicolumn{1}{c|}{ DEFINITION } \\
\hline Collagen & 1 to 4 & Few=1; Medium=2; High=3; Massive=4 \\
Fibrosis & 1 to 4 & Few=1; Medium=2; High=3; Massive=4 \\
Fibroblasts & 1 to 4 & Global amount of fibroblasts \\
Foreign body reaction & -1 to -4 & $\begin{array}{l}\text { Reaction intensity } \\
\text { Inflammation }\end{array}$ \\
\hline
\end{tabular}




\section{Statistics}

Statistical analysis was performed using SPSS 17.0 software through analysis of variance (ANOVA) followed by Student's t-test and the nonparametric Mann Whitney, considering significant differences at $p<0.05$.

\section{RESULTS}

Table 1 - Descriptive statistics results of the variable resistance of the intestinal anastomosis, weight and their inferential statistical tests.

\begin{tabular}{|c|c|c|c|}
\hline \multirow{2}{*}{ Variables } & \multicolumn{2}{|c|}{ Groups } & \multirow{2}{*}{ P-value } \\
\hline & Anastomosis $^{2}$ & Anastomosis+shock ${ }^{2}$ & \\
\hline Prior weight (g) & $375.8 \pm 27.1^{¥}$ & $373.7 \pm 19.5 \dagger$ & $0.877^{1}$ \\
\hline Weight after (g) & $361.7 \pm 24.1^{¥}$ & $359.7 \pm 19.3 †$ & $0.877^{1}$ \\
\hline Pressure (mmHg) & $69.3 \pm 3.8^{*}$ & $57.3 \pm 4.5^{*}$ & $0.001^{1}$ \\
\hline \multicolumn{4}{|c|}{$\begin{array}{l}\text { Mean } \pm \text { Standard deviation } \\
1-p \text {-value of Student's t-testfor independent samples. } \\
2-\text { Values }- \text { from the column- followed by similar symbols presented statistically significant } \\
\text { differences between groups, according to Student's t-test for paired samples. }\end{array}$} \\
\hline
\end{tabular}

In Table 1 it is observed that the variable prior weight and weight after interventions had no significant difference between the groups anastomosis and anastomosis+shock (P-value 0.877). The variable pressure, on the other hand, demonstrated that the anastomosis+shock group rats presented a decrease in intestinal anastomosis bursting pressure in comparison to the anastomosis group, which difference was significant $(p=0.001)$. This last data corroborates the hypothesis that the hypovolemic shock has deleterious effects on the healing process of intestinal anastomoses.

Table 2 - Results of histopathological exams and their respective inferential statistical test.

\begin{tabular}{lccc}
\hline \multirow{2}{*}{ Variables } & \multicolumn{2}{c}{ Groups } & \multirow{2}{*}{ P-value $^{1}$} \\
\cline { 2 - 3 } & Anastomosis & Anastomosis+shock & \\
\hline Collagen & $3.33 \pm 0.51$ & $1.83 \pm 0.75$ & 0.007 \\
Fibrosis & $2.17 \pm 0.75$ & $1.33 \pm 0.52$ & 0.057 \\
Fibroblasts & $2.00 \pm 0.0$ & $2.00 \pm 0.0$ & 1.000 \\
Inflammation & $-1.67 \pm 0.62$ & $-2.80 \pm 0.55$ & 0.043 \\
Reaction (foreign body) & $-0.67 \pm 0.52$ & $-1.83 \pm 0.41$ & 0.006 \\
\hline
\end{tabular}

Mean \pm Standard deviation

1 - $p$-value of the non-parametric Mann Whitney's test. 
In Table 2 it can be observed than in the group of animals subjected to hemorrhagic shock occurred less intense formation of collagen and fibrous tissue and greater inflammation and foreign body reaction than in the anastomosis group, featuring a more immature and deficient healing. Figures 1 and 2 show histological data from representative experimental units of the two studied groups.

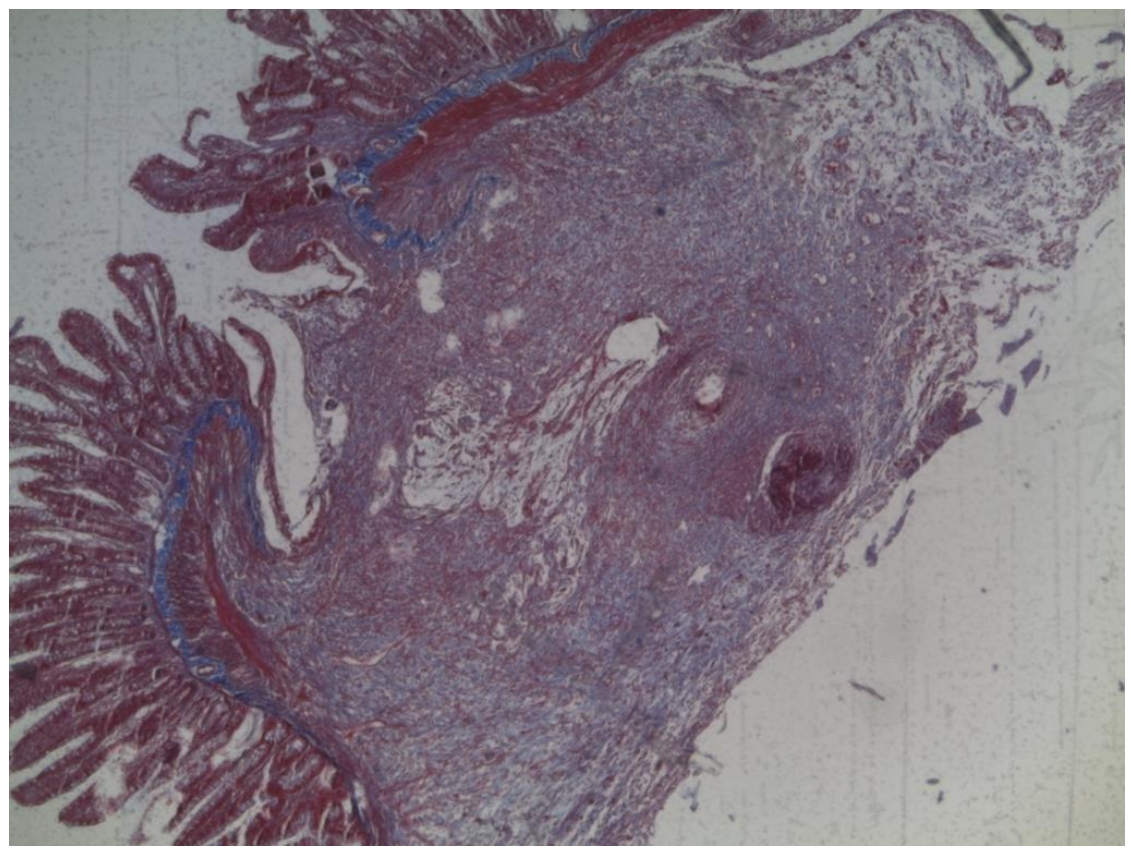

Figure 1 - Representative photomicrograph of ileal anastomosis zone of animal from anastomosis+hemorrhagic shock group. There is a low degree of mucosal regeneration, intense inflammation and foreign body reaction. Masson trychrome- 200x.

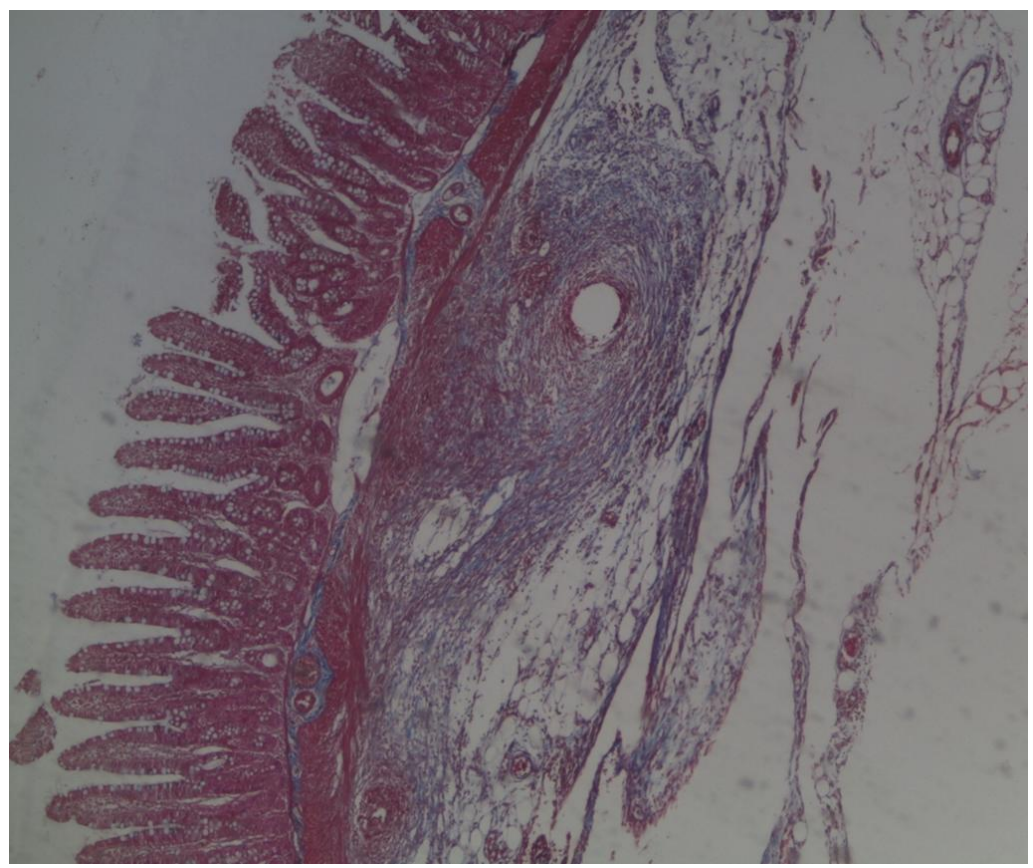

Figure 2 - photomicrograph of ileal anastomotic area of rat from anastomosis group. It is observed good regeneration of the mucosa, little inflammation and collagen fibers in satisfactory level. Masson trychrome, 200x. 


\section{DISCUSSION}

Studies show that the incidence of traumatic lesions of the small intestine in developing countries exceeded the spleen and liver lesions. Often, these lesions are associated with trauma of other organs and circulatory decompensation states, making it difficult to evaluate the individual effect of each involved factor. Some of the systemic factors that influence the healing process of intestinal anastomoses are poor nutrition, blood transfusion, chemotherapy, immunodeficiency and hypovolemic shock ${ }^{13}$.

Hypoperfusion in intestinal segments, as in hypovolemic shock, depending on its intensity and duration, could lead to ischemic injury of the mucosa, promoting disastrous consequences such as bacterial translocation, systemic inflammatory response syndrome and multiple organ and systemic failure ${ }^{14}$.

Despite its clinical importance, during the development of this research it was realized that this issue is still little explored in the literature and, when approached, it is evaluated as a benchmark of the healing of the colon and not a central target of the investigations. In these studies it is observed that despite an intensified preoperative care and advances in techniques in colorectal surgery over the years, the dehiscence of the anastomosis is the most feared complication in the postoperative period being reported prevalence ranging from 1 to $39 \%$, but clinically significant are possibly 3 to $6 \%$ of the cases, depending on the type of resection performed ${ }^{15}$. Therefore, this complication contributes considerably to postoperative morbidity, increased length of hospital stay, and it generates extra costs ${ }^{15,16}$. For example, dehiscence of the anastomosis remains a lifethreatening condition associated with the rate of $13 \%$ mortality ${ }^{15}$. Notably, patients develop an agonizing abdominal pain, stiff abdomen, tachycardia, high fever, and hemodynamic instability ${ }^{17}$. In such cases, it is necessary to return urgently to the operating room for a revision of the surgery and for appropriate treatment. Prolonged periods in the Intensive Care Unit and death are not uncommon ${ }^{17}$. Therefore, knowledge of the factors that influence the healing of the anastomoses is of utmost importance, especially regarding the management of the consequences in the perioperative or technical considerations for surgery ${ }^{16}$.

About the risk factors for colorectal anastomoses dehiscence, according to a multivariate analysis, they are: score on the American Society of Anesthesiologists (ASA) score of perioperative risk and postoperative progress greater or equal to three, prolonged surgical time (over three hours) and anastomoses without peritoneal protection ${ }^{15}$. Thus, it is important to identify the perioperative risk factors to be able to adapt the surgical strategy towards a better prognosis. 
Clearly, as above mentioned, there are studies using the same experimental model in colorectal resection. Undeniably, it is important to know the risk factors of anastomotic dehiscence in this segment, however, there are few studies about anastomoses of the small intestine, despite its clinical and surgical importance. Moreover, as much as hemorrhagic shock is included among the risk factors for intestinal anastomoses ${ }^{18}$, its damage to the small bowel anastomoses has not been studied ${ }^{6}$. When the results of the groups regarding the gas insufflation test were analyzed, it was observed that in the group anastomosis + shock the rupture pressure of the bowel suture was significantly lower than in the group anastomosis at the 6th postoperative day (POD). This suggests that the hypovolemic shock promotes some ischemic changes on the wall of the ileum, leading to lower resistance of the intestinal wall to gaseous distention. When we analyzed the location of the intestinal rupture after the gas insufflation test, it was observed that the healing wounds were all ruptured at the site of anastomosis at the 6th POD, denoting that, at this monitoring period, the site of weakness is concentrated at the site of intestinal anastomosis. This finding suggests that the hypovolemic shock altered in some way the normal evolution of the healing process of intestinal anastomoses during the study period.

At the same time, if we consider that a hemorrhagic shock situation is an important systemic disorder, difficult to control, with impact on anesthesia and surgery, hemorrhagic shock could be a known risk factor for dehiscence of colorectal anastomoses. Similarly, this study showed that hypovolemic shock carries deleterious effects on the healing process of ileal anastomoses, demonstrating that the anastomosis + shock group presented a significant decrease in intestinal rupture pressure in relation to anastomosis group. Similar fact was also confirmed by an experimental study ${ }^{6}$ which evaluated five groups - standard, shock, anastomosis, shock + anastomosis, and shock + anastomosis+ volume replacement. The study noted that, histologically, hypovolemic shock causes progressive changes in the intestinal anastomoses, including injury of mucous membrane and the increase in the deposition of collagen fibers in the submucosa, with the evolution of the postoperative period. Likewise, significant histopathological changes were observed in this research in the animals from the shock + anastomosis group when compared to the isolated anastomosis group. Other studies have analysed shock and ihealing ${ }^{20,21}$. The low blood flow states have been shown as a cause of injury to the mucosal barrier with consequent decrease in intestinal absorption capacity, probably because of histological changes that occur in the small intestine as a result of hemorrhagic shock ${ }^{22,23}$. 
In conclusion, the results show that the hypovolemic shock affects the wound healing, causing a decrease in the rupture pressure ofileal anastomoses, leading to the fragility of the surgical wound.

\section{REFERENCES}

1. Pereira YEA, Fagundes JJ, Morandini RC, Ayrizono MLS, Nascimento BR, Leal RF et al. Hemorrhagic shock influence on colonic anastomoses in rats. Evaluation of rupture by liquid distension resistance test. Acta Cir Bras. 2008;23:237-42.

2. Coutinho IHILS, Torres OJM, Matias JEF, Coelho JCU, Júnior HJS, Agulham MA, et al. Efeito do extrato hidroalcoólico de aroeira (Schinus Terebinthi folius Raddi) na cicatrização de anastomoses colônicas. Estudo experimental em ratos. Acta Cir Bras.2006;21 (suppl.3):49-54.

3. Thornton FJ, Barbul A. Healing in the gastrointestinal tract. Surg Clin North Am. 1997;77: 549-73.

4. Baffa LP, Garcia RLS, CamposAD, Rocha JJR, Feres O. Efeito da anemia aguda na cicatrização de anastomoses colônicas. Estudo experimental em ratos. Rev Bras Coloproct. 2005; 25(1): 24-30.

5. Bolzam-Nascimento R, Coy CSR, Pereira YEA, Leal RF, Reis RCM, Mantovani M, et al. Influence of omentoplasty on colonic anastomosis in animals submitted to hemorrhagic shock in rats. Acta Cir Bras 2009;24:233-8.

6. Brito MVH, Koh IHJ, Lamarao LG andDamous SHB. Efeito do choque hipovolêmico na anastomose do intestino delgado de ratos. ArqGastroenterol. 2001; 38: 116-24.

7. Meletti JFA, Módolo NSP. Hemorrhagic Shock Hemodynamic and Metabolic Behavior: Experimental Study in Dogs. Rev Bras Anestesiol. 2003;53:623 - 32.

8. Abreu GFS, Coelho ARB, Aguiar JLA, Moura Filho, AS. Cardiocirculatory changes in hemorrhagic shock induced in pigs submitted to three distinct therapeutic methods. Acta Cir Bras. 2009; 24 (6): 126-30.

9. Greca FH, Biondo-Simões MLP, De Paula JB, Noronha L, Cunha LSF, Baggio PV et al. Correlação entre o fluxo sanguíneo e a cicatrização de anastomose colônicas: estudo experimental em cães. Acta Cir Bras. 2000; 15 (suppl3): 88-94.

10. Laund F, Féres O, Rocha JJR, Campos AD, Carvalho FG. Efeito da Hipovolemia Sobre a Cicatrização de Anastomoses Colônicas. Estudo Experimental em Ratos. Rev Bras Coloproct. 2004; 24(4): 317-21.

11. Wu X, Zhang Y, Yin Y, Ruan Z, Yu H, Wu Z, Wu G. Roles of heat-shock protein 70 in protecting against intestinal mucosal damage. Front Biosci. 2013;18:356-65.

12. Homma H, Hoy E, Xu DZ, Lu Q, Feinman R, Deitch EA. The female intestine is more resistant than the male intestine to gut injury and inflammation when subjected to conditions associated with shock states. Am J Physiol Gastrointest Liver Physiol. 2005;288:G466-72.

13. Cavazzola LT et al. Condutas em cirurgia geral, Porto Alegre: Artmed; 2008.

14. Brito MVH, Nigro AJT, Montero EFS, Nascimento JLM, Silva PRF, Siqueira RBP. Viabilidade celular do intestino delgado de ratos, após correção de choque hipovolêmico solução de $\mathrm{NaCl}$ 7,5\%. Acta Cir Bras 2003 Jul-Ago;18(4).

15. Buchs NC, Gervaz P, Secic M, Bucher P, Mugnier-Konrad B, Morel P. Incidence, consequences, and risk factors for anastomotic dehiscence after colorectal surgery: A prospective monocentric study. Int J Colorectal Dis. 2008;23(3):265-70. 
16. Kruschewski M, Rieger $\mathrm{H}$, Pohlen U, Hotz HG, Buhr HJ. Risk factors for clinical anastomotic leakage and postoperative mortality in elective surgery for rectal cancer.Int J Colorectal Dis. 2007;22(8):919-27.

17. Hyman N, Manchester TL, Osler T, Burns B, Cataldo PA. Anastomotic leaks after intestinal anastomosis: It's later than you think. Ann Surg. 2007;245(2):254-8.

18. Guyton AC. Tratado de fisiologia médica. 8.ed. Rio de Janeiro: Guanabara Koogan; 1992.

19. Storch M, Perry LC, Davidson JM, Ward JJ. A 28-day study of the effect of Coated VICRYL* Plus Antibacterial Suture (coated polyglactin 910 suture with triclosan) on wound healing in guinea pig linear incisional skin wounds. Surg Infect. 2002;3Suppl 1:S89-98.

20. Felipe JC, Nascimento LAT, Souza GSS, Toledo LN, Medeiros VB, Azevedo IM, Medeiros AC. Coconut water as a resuscitation fluid and their effect on colon anastomosis healing in rats with hemorrhagic shock. J Surg CII Res. 2014;5:80-91.

21. Farias DC, Mariz JC, Silva PMN, Medeiros VFLP, Macedo-Filho R, Carvalho MD F, Araújo-Filho Irami, Rego ACM, Azevedo IM, Medeiros AC. Volume replacement with coconut water in rats with hemorrhagic shock. J Surg Cl Res. 2013;4:35-44.

22. Schein RSM, Macfarlane C, Boffard KD. Gut barrier function and the surgeon. $\mathrm{Br} J$ Surg 1990;77:487-92.

23. Singh G, Chaudry KL, Chaudry IH. Restoration of gut absortive capacity following trauma-hemorrhagic shock by the adjuvant use of heparan sulfate.J Trauma 1993;34:645-52. 